\title{
PENGARUH MODAL INTELEKTUAL TERHADAP KINERJA KEUANGAN PERUSAHAAN (STUDI EMPIRIS PADA BURSA EFEK INDONESIA)
}

\author{
Helmi Herawati \\ Program Studi Akuntansi \\ Fakultas Ekonomi Universitas Prof DR Hazairin SH Bengkulu \\ helmiherawati77@gmail.com
}

\begin{abstract}
ABSTRAK
Helmi Herawati; Penelitian modal intelektual di Indonesia berawal dari Munculnya PSAK No.19 yang merupakan awal berkembangnya modal intelektual. PSAK No.19. Data yang akan digunakan dalam penelitian ini adalah seluruh perusahaan yang listing di BEI dengan menggunakan laporan keuangan tahunan yang diperoleh dengan database online http://www.idx.co.id/. Besarnya jumlah sampel yaitu sebanyak 397 perusahaan yang listing di BEI, dengan menggunakan teknik porposive sampling yaitu merupakan tipe pemilihan sampel secara acak yang informasinya diperoleh dengan menggunakan pertimbangan tertentu atau dengan tujuan untuk mendapatkan sampel yang representative sesuai dengan kriteria yang ditentukan. Berdasarkan hasil pengujian dengan PLS diketahui bahwa IC (VAIC) tidak berpengaruh positif terhadap kinerja keuangan perusahaan. Sehingga dengan demikian berarti H1 tidak dapat diterima.Dari hasil pengujian PLS mengindikasikan bahwa IC (VAIC) secara positif tidak berpengaruh terhadap kinerja keuangan perusahaan masa depan. Sehingga dengan demikian berarti $\mathrm{H} 2$ tidak terbukti.Dari hasil pengujian PLS menyajikan bukti bahwa tidak ada pengaruh positif ROGIC terhadap kinerja keuangan.Dari Hasil pengujian PLS menunjukkan bahwa kontribusi IC untuk sebuah kinerja masa depan perusahaan tidak terdapat perbedaan sesuai dengan jenis sektor perusahaannya. Sehingga dengan demikian berarti H4 ditolak.
\end{abstract}

\section{ABSTRACT}

Helmi Herawati; The study of intellectual capital in Indonesia originated from the emergence of PSAK No.19 which was the beginning of the development of intellectual capital. PSAK No.19. The data to be used in this study is all companies listing on the BEI using annual financial statements obtained with online database http://www.idx.co.id/. The amount of sample is as many as 397 companies listing on BEI, using the technique of sampling sampling is a type of random sample selection of information obtained by using certain considerations or with the aim to obtain a representative sample in accordance with the criteria specified. Based on the results of testing with PLS note that IC (VAIC) does not positively affect the financial performance of the company. Hence, therefore, $H 1$ is not acceptable. From the result of PLS testing indicates that IC (VAIC) positively has no effect on future company's financial performance. Hence it means that H2 is not proven. From the result of testing of PLS present proof that there is no positive influence of ROGIC to financial performance. From result of PLS test show that IC contribution to a future performance of company there is no difference according to type of company sector. So that means H4 is rejected.

Key Words: Intangible Assets, Intellectual Capital, Corporate Financial Performance.

\section{PENDAHULUAN}

Penelitian modal intelektual di Indonesia berawal dari Munculnya PSAK No.19 yang merupakan awal berkembangnya modal intelektual. PSAK No.19 berisi tentang aktiva tidak berwujud merupakan aktiva non-moneter yang dapat diidentifikasi dan tidak mempunyai wujud fisik serta dimiliki untuk digunakan dalam menghasilkan atau menyerahkan barang atau jasa, disewakan kepada pihak lainnya, atau untuk tujuan administratif (IAI,2007). Jadi amat sangat jelas bahwa aktiva tidak berwujud itu sebenarnya ada namun tidak ada wujudnya.

Perbedaan antara aset tak berwujud dan modal intelektual tidak jelas karena modal intelektual dihubungkan dengan goodwill padahal keduanya berbeda. Fakta ini dapat ditelusuri dengan kembali ke awal tahun 1980-an ketika gagasan umum nilai aset tak berwujud dinamakan goodwill. Hal ini mulai diterapkan sejak praktik bisnis dan akuntansi. Pada praktik akuntansi secara tradisional tidak juga mangungkapkan pengukurannya. Aset tidak berwujud seperti modal merk, paten dan goodwill jarang sekali dilaporkan pada laporan keuangan (Kuryanto, 2007).

Pengukuran yang tepat modal intelektual masih belum ditetapkan, misalnya, Pulic tidak mengukur secara langsung IC perusahaan, tetapi mengajukan suatu ukuran untuk menilai efisiensi dari 
nilai tambah sebagai hasil dari kemampuan intelektual perusahaan (Value Added Intellectual Coefficient VAIC $^{\mathrm{TM}}$ ). Komponen utama dari VAIC ${ }^{\mathrm{TM}}$ dapat dilihat dari sumber daya perusahaan, yaitu physical capital (VACA - value added capital employed), human capital (VAHU - value added human capital), dan structural capital (STVA - structural capital value added) ( Ulum, 2007).

Seperti yang diungkap oleh Murti (2010) Penelitian tentang modal intelektual layak dilakukan di Indonesia karena terdapat keputusan Ketua Badan Pengawas Pasar Modal dan Lembaga Keuangan Nomor: Kep-134/BL/2006 tentang kewajiban penyampaian laporan tahunan bagi emiten atau perusahaan publik. Dimana salah satu ketentuannya adalah laporan tahunan wajib memuat ikhtisar data keuangan penting, laporan dewan komisaris, laporan direksi, profil perusahaan, analisis dan pembahasan manajemen, tata kelola perusahaan, tanggung jawab direksi atas laporan keuangan, dan laporan keuangan yang telah diaudit.

Penelitian ini mengacu pada penelitian yang perhah dilakukan oleh Ulum dan juga Kuryanto pada tahun 2007. Dengan rentang tahun penelitian yang digunakan dalam penelitian ini adalah dari tahun 2005-2009 dengan menggunakan seluruh perusahaan yang listing di Bursa Efek Indonesia.

\section{TINJAUAN PUSTAKA}

Teori yang digunakan dalam penelitian ini adalah stakeholder theory yang isinya adalah lebih mempertimbangkan posisi para stakeholder yang dianggap powerfull. Stakeholder menjadi pertimbangan yang utama bagi perusahaan dalam pengungkapan atau tidak diungkapkannya suatu bentuk informasi kedalam laporan keuangan perusahaan.

Menurut Meek dan Gray (1988) bahwa value added adalah ukuran yang lebih akurat yang dicipatakan stakeholder yang sama sementara konsensus berkembang dalam konteks teori stakeholder adalah bahwa laba akuntansi hanyalah merupakan ukuran return bagi pemegang saham. Value added dan return diharapkan dapat menjelaskan teori stakeholder dalam pengukuran kinerja keuangan suatu perusahaan (Ulum, 2007).

Resource-Based Theory merupakan suatu aliran baru yang dibuat untuk memahami bagaimana organisasi-organisasi mencapai keunggulan kompetitif secara berkelanjutan. Teori ini merupakan sebuah keunggulan dalam ilmu pengetahuan (knowledge/learning economy) atau perekonomian yang berdasarkan pada aset tak berwujud. Resources Based Theory dipelopori oleh Penrose pada tahun 1959 menyatakan bahwa sumber daya perusahaan adalah heterogen, tidak homogen, jasa produktif yang tersedia berasal dari sumber daya perusahaan yang memberikan karakter unik bagi tiap-tiap perusahaan (Artinah, 2010).

Resource-based theory, merupakan suatu strategi keunggulan bersaing hanya terjadi jika ada situasi heterogenitas sumberdaya (sumberdaya yang berbeda-beda pada perusahaan-perusahaan) dan imobilitas sumberdaya (ketidakmampuan perusahaan-perusahaan yang bersaing untuk mendapatkan sumberdaya dari perusahaan-perusahaan lain) (Barney, 1991).

\section{Aktiva Tidak Berwujud}

Aktiva tidak berwujud dapat diidentifiksikan secara khusus yaitu terdiri dari paten, hak cipta, merek dagang dan nama dagang, leasehold, waralaba dan lisensi. Hal ini hampir sama seperti yang disebutkan oleh Ting dan lean (2009) yaitu aktiva tidak berwujud terdiri dari paten, merek dagang, hak cipta dan dapat dimasukkan kedalam laporan keuangan tradisional. Hal ini merupakan bentuk dari modal intelektual. Modal intelektual adalah sebagai suatu proses pengelolan teknologi yang mengkhususkan untuk menghitung prospek perusahaan dimasa yang akan datang, kategori intangible asset merupakan sesuatu yang berhubungan dengan teknologi, konsumen, kontrak, proses data, modal personal,pemasaran, lokasi dan goodwill.

Berbagai upaya pengukuran dan pengungkapan modal intelektual telah lama dilakukan dengan menggunakan berbagai macam pendekatan. Saputro (2001) menyampaikan bahwa ada mengunakan dengan standar akuntansi, dan juga informasi tambahan dalam laporan keuangan dan pendekatan dengan menggunakan disclosure.

Sebagai upaya pertama adalah dengan pendekatan standar akuntansi yaitu international accounting standars (IAS) merupakan standar yang didalamnya dimasukkan unsur modal intelektual. IAS juga digunakan untuk mendekati masalah modal intelektual dalam IAS No. 38 tentang intangible assets. IAS No. 38 ini merupakan pengembangan dari IAS No. 9 yaitu tentang riset dan pengembangan. Akan tetapi IAS No. 38 belum sepenuhnya membahas semua unsur modal intelektual. Menurut IAS No.38 intangible assets sebaiknya diakui sejak awal pada cost-nya dalam laporan keuangan. 
Setelah pengakuan awal dalam laporan keuangan, intangible assets sebaiknya diukur dengan menggunakan salah satu dari dua perlakuan berikut ini (Saputo,2001):

1. Benchmark treatment, yaitu histrorical cost dikurangi amortisasi lainnya dan impairment losses.

2. Allowed alternatif treatment, yaitu jumlah yang direvaluasi (mendasarkan pada nilai pasar) dikurangi amortasasi dan impairment losses.

Upaya kedua adalah dengan memberikan informasi tambahan dalam laporan keuangan, ini merupakan pendekatan yang relevan tentang modal intelektual yaitu dalam bentuk tambahan laporan atau juga informasi tambahan untuk mendukung informasi yang ada dalam laporan keuangan.

Upaya ketiga yaitu dengan mengungkapkan informasi modal intelektual dalam bentuk disclosure. Pengungkapan dengan cara ini dilakukan bila pengukuran sulit dilakukan, meskipun akuntan juga memiliki keterbatasan pengetahuan dalam menyampaikan informasi, juga keterbatasan untuk memenuhi semua yang diinginkan oleh para pemakai. Hal ini menyebabkan untuk mempertahankan pada satu pilihan pelaporan untuk digunakan kedalam berbagai kepentingan. Konsekuensinya adalah pilihan yang sulit ini diatasi dengan pengungkapan disclosure yang jauh lebih rinci.

Saputro (2001) manyatakan bahwa dalam SFAC No.1 juga menegaskan bahwa informasi yang disediakan oleh pelaporan keuangan dikuantitaskan dan dinyatakan dengan satuan uang. Apabila ada informasi lain yang dipandang perlu dapat dinyatakan dengan menggunakan pengungkapan.

\section{Modal Intelektual}

Pengertian modal intelektual dari organisation for economic co-operation and development (OECD, 1999) memberi penjelasan tentang modal intelektual adalah sebagai nilai ekonomi dari 2 kategori aset tak berwujud: 1.organisational (structural) capital; dan 2. Human capital. Untuk memahami apa itu modal intelektual bisa dilihat pengertian modal intelektual dari para peneliti sebelumnya. Namun banyak para penulis sebelumnya mendefinisikan modal intelektual ini berbeda - beda. Menurut Steward (1997)dalam Anatan (2004) mendefinisikan modal intelektual sebagai materi intelektual yaitu pengetahuan informasi, kekeyaan intelektual, pengalaman yang digunakan untuk mengungkapakan kesejahteraan. Steward juga berpendapat bahwa pengetahuan merupakan faktor produksi yang penting dan oleh karena itu maka aset intelektual ini harus dikelola oleh perusahaan.

Dengan pengertian yang berbeda-beda ini menimbulkan banyak organisasi mengembangkan difinisi mereka sendiri. Skandia insurance company (1998) mendifinisikan modal intelektual "memiliki pengetahuan, pengalaman diterapkan, teknologi organisasi, hubungan pelanggan dan keterampilan profesional yang menyediakan perusahaan dengan kompetitif pasar" (Ting dan lean, 2009). Masih Menurut Ting dan lean, (2009) bahwa modal intelektual ini menimbulkan kebingungan karena modal intelektual berbeda dengan aktiva tidak berwujud.

Society of management accounting of canada (SMAC,1998), mendifinisikan modal intelektual sebagai item pengetahuan yang dimiliki oleh perusahaan, yang akan menghasilkan keuntungan dimasa yang akan datang bagi perusahaan.

\section{Kinerja Keuangan Perusahaan}

\section{Profitabilitas: Return on Assets (ROA)}

Merupakan profitabilitas yang mengukur jumlah profit yang diperoleh pada setiap rupiah aset yang dimiliki oleh perusahaan. ROA dapat memperlihatkan kemampuan perusahaan dalam melakukan efisiensi penggunaan total aset untuk operasional perusahaan. ROA juga bisa memberikan gambaran pada investor tentang bagaimana mengkonversikan uang yang telah diinvestasikan. ROA ini merupakan indikator dari profitabilitas perusahaan dalam menggunakan asetnya untuk menghasilkan laba bersih (Pramelasari,2010).

2. Pertumbuhan pendapatan (GR)

Earning merupakan suatu ukuran berapa besar harta yang masuk (pendapatan) melebihi harta yang keluar (biaya dan kerugian) suatu perusahaan selama periode tertentu (Santoso, 2010).

\section{Size Perusahaan}

Size perusahaan bisa didasarkan pada jumlah tenaga kerja, volume penjualan dan kapitalisasi pasar. Pada penelitian ini size perusahaan dinyatakan dengan jumlah tenaga kerja pada perusahaan yang sudah terdaftar di BEI. Pengukuran ini dilakukan untuk mengetahui bahwa semakin besar jumlah tenaga kerja yang dimiliki maka akan semakin besar pula tanggung jawab sosial yang harus diungkapkan (Cahya,2010). 


\section{Kerangka Analisis}

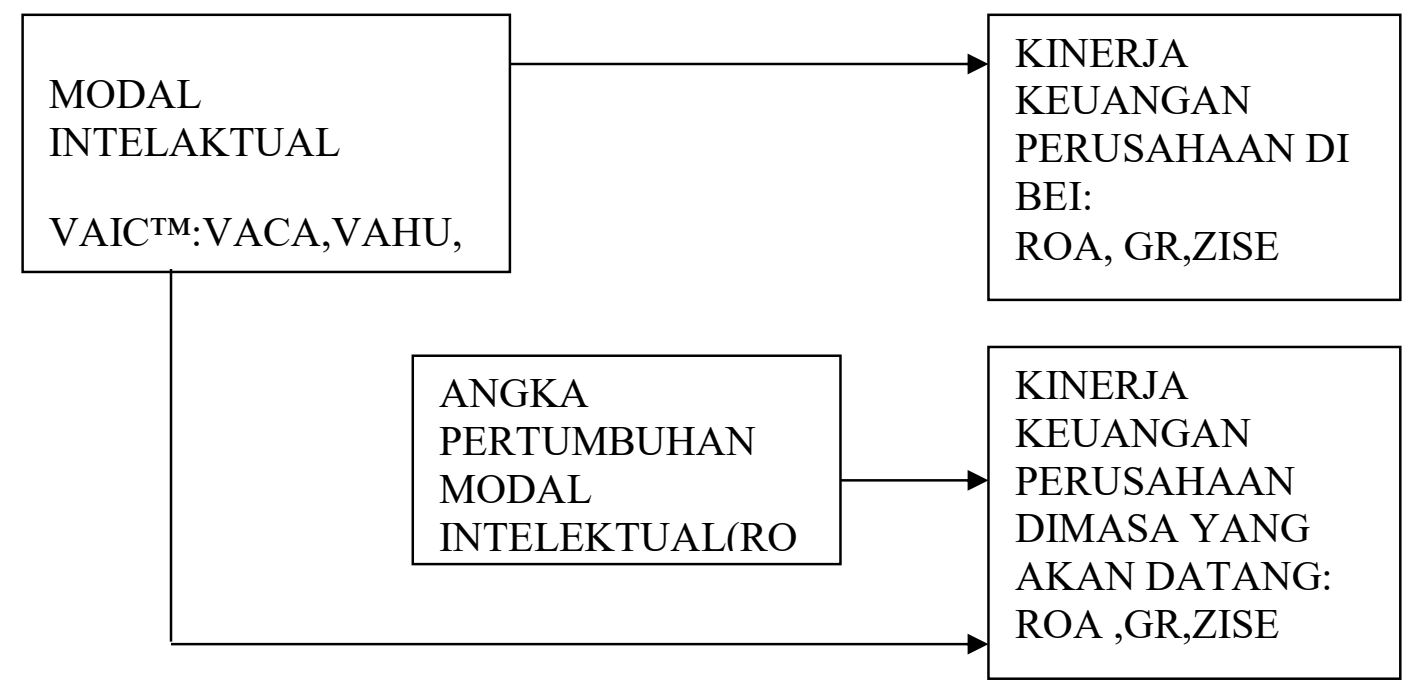

Gambar 1. Kerangka Analisis

\section{Hipotesis Penelitian}

H1 : Terdapat pengaruh positif modal intelektual terhadap kinerja keuangan perusahaan.

H2 : Terdapat pengaruh positif modal intelektual (VAIC ${ }^{\text {TM }}$ ) terhadap kinerja keuangan perusahaan masa depan.

H3: Terdapat pengaruh positif tingkat pertumbuhan intellectual capital (ROGIC) terhadap kinerja keuangan perusahaan masa depan.

H4 : Kontribusi modal intelektual untuk sebuah kinerja masa depan perusahaan akan berbeda sesuai dengan jenis industrinya.

\section{METODE PENELITIAN}

Data yang akan digunakan dalam penelitian ini adalah seluruh perusahaan yang listing di BEI dengan menggunakan laporan keuangan tahunan yang diperoleh dengan database online http://www.idx.co.id/. Besarnya jumlah sampel yaitu sebanyak 397 perusahaan yang listing di BEI, dengan menggunakan teknik porposive sampling yaitu merupakan tipe pemilihan sampel secara acak yang informasinya diperoleh dengan menggunakan pertimbangan tertentu atau dengan tujuan untuk mendapatkan sampel yang representative sesuai dengan kriteria yang ditentukan.

Adapun kriteria yang digunakan untuk memilih sampel adalah sebagai berikut : Mempublikasikan laporan keuangan selama lima tahun berturut-turut untuk periode 2005 dan 2009. Perusahaan memiliki data yang lengkap terkait dengan aset, ekuitas, pendapatan, beban, biaya karyawan, laba bersih dan juga jumlah karyawan. Memperoleh laba bersih selama lima tahun berturut-turut untuk periode 2005, $2006,2007,2008$ dan 2009.

\section{Variabel penelitian dan definisi operasional veriabel}

Variabel independen dalam penelitian ini adalah IC yang diukur berdasarkan value added yang diciptakan oleh physical capital (VACA), human capital (VAHU), dan structural capital (STVA). Kombinasi dari ketiga value added tersebut disimbolkan dengan nama VAIC ${ }^{\mathrm{TM}}$ yang dikembangkan oleh Pulic (1998; 1999; 2000).

Pada penelitian ini variabel Dependen yang digunakan adalah

1. Return on assets (ROA).

ROA merefleksikan keuntungan bisnis dan efisiensi perusahaan dalam pemanfaatan total asset (Chen et. al., 2005).

ROA = Laba bersih

2. GR.

$$
\text { total asset }
$$

GR mengukur perubahan pendapatan perusahaan. Peningkatan pendapatan biasanya merupakan sinyal bagi perusahaan untuk dapat tumbuh dan berkembangan Chen et al Dalam Ulum (2007). 
$\mathrm{GR}=\{($ Pendapatan tahun ke-t $\div$ Pendapatan tahun ke-t-1) -1$\} \times 100 \%$

3. Zise.

Pengukuran dengan menggunakan zise ini dilakukan untuk mengetahui bahwa semakin besar jumlah tenaga kerja yang dimiliki maka akan semakin besar pula tanggung jawab sosial yang harus diungkapkan (Cahya,2010).

\section{HASIL DAN PEMBAHASAN \\ Pengujian Statistik Dekskriptif}

Uji statistik deskriptif bertujuan untuk memberikan gambaran atau deskripsi dari suatu data yang dilihat dari jumlah sampel, nilai minimum, nilai maksimum, nilai rata-rata (mean), dan standar deviasi dari masing-masing variabel.

Tabel 1. Statistik Deskriptif

Descriptive Statistics

\begin{tabular}{|l|r|r|r|r|r|}
\hline & $\mathrm{N}$ & \multicolumn{1}{|c|}{ Minimum } & \multicolumn{1}{c|}{ Maximum } & \multicolumn{1}{c|}{ Mean } & \multicolumn{1}{c|}{ Std. Deviation } \\
\hline ROA & 84 & .01 & 27.98 & 5.8802 & 4.98519 \\
GR & 84 & -1.00 & .71 & .1853 & .26535 \\
SIZE & 84 & 5.85 & 10.02 & 7.5870 & 1.09754 \\
VACA & 84 & -4.85 & 1664.95 & 61.3330 & 209.03061 \\
VAHU & 84 & -46307.00 & 7224.65 & 125.9425 & 5262.24729 \\
STVA & 84 & -2.10 & 1.00 & .8656 & .52464 \\
Valid N (listwise) & 84 & & & & \\
\hline
\end{tabular}

Sumber: data sekunder yang diolah

Data pada tabel 1. menunjukkan, VAHU memiliki nilai tertinggi dibanding kedua komponen yang lainnya. Hal ini menunjukkan bahwa VAHU memberi kontribusi yang paling besar terhadap penciptaan value added perusahaan dimana VAHU diindikasikan berasal dari karyawan. Dalam penelitian ini, VAHU menunjukkan nilai 5262,25 yang berarti bahwa setiap Rp 1 pembayaran gaji mampu menciptakan value added sebesar 5262,25 kali lipat. Untuk VACA, nilai 209,03 menunjukkan bahwa aset yang dimiliki mampu memberikan value added sebesar 209,03 kali lipat dari nilai aset tersebut.

Sedangkan STVA sebesar 0,525 dapat diartikan bahwa structural capital memberikan 52,5\% untuk value added perusahaan.

Nilai mean ROA adalah sebesar 5,88 menunjukkan kemampuan perusahaan dapat menghasilkan setiap rupiah dari modal pemegang saham. Hal ini berarti perusahaan mampu menghasilkan laba sebesar Rp 5,88 untuk setiap Rp 1 jumlah dana pemegang saham. Untuk GR, nilai meannya adalah sebesar 0,185 . Hal ini menunjukkan bahwa terdapat perubahan pendapatan perusahaan sebesar $18,5 \%$.

Dari tabel 1. di atas juga memberikan sejumlah informasi, antara lain bahwa variabel GR, VACA dan VAHU memiliki penyimpangan data yang relatif besar, hal ini dapat diketahui dari lebih besarnya angka standar deviasi dibanding dengan angka rata-rata atau mean. Sedangkan variabel ROA, Size dan STVA diketahui tidak memiliki penyimpangan data yang relatif besar, karena angka mean yang lebih besar daripada angka pada deviasi standar. Selisih antara nilai minimum dengan nilai maksimum relatif cukup tinggi, ini menunjukkan bahwa terjadi fluktuasi data antar periode waktu.

\section{One Way Anova}

Prosedur yang digunakan dalam analisis ANOVA ini disebut dengan perancangan sebuah faktor, yang merupakan salah satu alat analisis statistik ANOVA yang bersifat satu arah (satu jalur). ANOVA merupakan metode untuk menguji hubungan antara satu variabel dependen (skala metrik) dengan satu atau lebih variabel independen (skala non metrik atau kategorikal dengan kategori lebih dari dua).

One Way between groups ANOVA dilakukan pada ketiga kelompok perusahaan untuk menentukan apakah kinerja keuangan perusahaan dengan IC yang lebih tinggi secara statistik berbeda dengan IC yang lebih rendah untuk setiap tahun 2006 sampai 2008. Hasil yang signifikan akan menunjukkan mean populasi secara statistik tidak sama antara perusahaan dengan IC yang lebih tinggi memiliki ukuran kinerja yang berbeda dibandingkan dengan IC perusahaan yang lebih rendah. 
Tabel 2. Hasil Anova 2006

ANOVA

\begin{tabular}{|ll|r|r|r|r|r|}
\hline & \multicolumn{1}{|c|}{$\begin{array}{c}\text { Sum of } \\
\text { Squares }\end{array}$} & df & Mean Square & \multicolumn{1}{c|}{ F } & Sig. \\
\hline ROA06 & Between Groups & 411.143 & 2 & 205.571 & 70.133 & .000 \\
& Within Groups & 73.280 & 25 & 2.931 & & \\
& Total & 484.422 & 27 & & & \\
\hline GR06 & Between Groups & .881 & 2 & .441 & 13.012 & .000 \\
& Within Groups & .847 & 25 & .034 & & \\
& Total & 1.728 & 27 & & & \\
\hline Size06 & Between Groups & 26.089 & 2 & 13.044 & 51.789 & .000 \\
& Within Groups & 6.297 & 25 & .252 & & \\
& Total & 32.386 & 27 & & & \\
\hline
\end{tabular}

Tabel 2. menunjukkan hasil ANOVA untuk data tahun 2006. Dari tabel tersebut terlihat bahwa $F$ ratio signifikan bagi keseluruhan data ROA 2006, GR 2006 maupun Size 2006. Dengan demikian, ROA, GR dan Size 2006 terdapat berbeda untuk perusahaan dengan IC lebih tinggi dibandingkan dengan IC yang lebih rendah.

Tabel 3. Hasil Anova 2007

\begin{tabular}{|c|c|c|c|c|c|c|}
\hline \multicolumn{7}{|c|}{ ANOVA } \\
\hline & & $\begin{array}{l}\text { Sum of } \\
\text { Squares }\end{array}$ & df & Mean Square & $\mathrm{F}$ & Sig. \\
\hline ROA07 & $\begin{array}{l}\text { Between Groups } \\
\text { Within Groups } \\
\text { Total }\end{array}$ & $\begin{array}{l}539.297 \\
380.152 \\
919.449\end{array}$ & $\begin{array}{r}2 \\
25 \\
27\end{array}$ & $\begin{array}{r}269.648 \\
15.206\end{array}$ & 17.733 & .000 \\
\hline GR07 & $\begin{array}{l}\text { Between Groups } \\
\text { Within Groups } \\
\text { Total }\end{array}$ & $\begin{array}{l}1.177 \\
1.286 \\
2.463\end{array}$ & $\begin{array}{r}2 \\
25 \\
27\end{array}$ & $\begin{array}{l}.589 \\
.051\end{array}$ & 11.444 & .000 \\
\hline Size07 & $\begin{array}{l}\text { Between Groups } \\
\text { Within Groups } \\
\text { Total }\end{array}$ & $\begin{array}{r}27.086 \\
5.762 \\
32.848 \\
\end{array}$ & $\begin{array}{r}2 \\
25 \\
27\end{array}$ & $\begin{array}{r}13.543 \\
.230\end{array}$ & 58.761 & .000 \\
\hline
\end{tabular}

Tabel 3. menunjukkan hasil ANOVA untuk data tahun 2007. Dari tabel tersebut terlihat bahwa $F$ ratio signifikan bagi keseluruhan data ROA 2007, GR 2007 maupun Size 2007. Dengan demikian, ROA, GR dan Size 2007 terdapat berbeda untuk perusahaan dengan IC lebih tinggi dibandingkan dengan IC yang lebih rendah.

Tabel 4. Hasil Anova 2008

\begin{tabular}{|c|c|c|c|c|c|c|}
\hline \multicolumn{7}{|c|}{ ANOVA } \\
\hline & & $\begin{array}{c}\text { Sum of } \\
\text { Squares }\end{array}$ & df & Mean Square & $\mathrm{F}$ & Sig. \\
\hline ROA08 & $\begin{array}{l}\text { Between Groups } \\
\text { Within Groups } \\
\text { Total }\end{array}$ & $\begin{array}{r}593.307 \\
59.663 \\
652.970\end{array}$ & $\begin{array}{r}2 \\
25 \\
27\end{array}$ & $\begin{array}{r}296.654 \\
2.387\end{array}$ & 124.305 & .000 \\
\hline GR08 & $\begin{array}{l}\text { Between Groups } \\
\text { Within Groups } \\
\text { Total }\end{array}$ & $\begin{array}{l}.535 \\
.102 \\
.637\end{array}$ & $\begin{array}{r}2 \\
25 \\
27\end{array}$ & $\begin{array}{l}.268 \\
.004\end{array}$ & 65.896 & .000 \\
\hline Size08 & $\begin{array}{l}\text { Between Groups } \\
\text { Within Groups } \\
\text { Total }\end{array}$ & $\begin{array}{r}28.562 \\
6.145 \\
34.707\end{array}$ & $\begin{array}{r}2 \\
25 \\
27\end{array}$ & $\begin{array}{r}14.281 \\
.246\end{array}$ & 58.101 & .000 \\
\hline
\end{tabular}

Tabel 4. menunjukkan hasil ANOVA untuk data tahun 2008. Dari tabel tersebut terlihat bahwa $F$ ratio signifikan bagi keseluruhan data ROA 2008, GR 2008 maupun Size 2008. Dengan demikian, ROA, GR dan Size 2008 terdapat berbeda untuk perusahaan dengan IC lebih tinggi dibandingkan dengan IC yang lebih rendah. 


\section{Analisis Korelasi Variabel Independen}

Analisis korelasi merupakan pengujian validitas yang penting untuk mengetahui apakah variabel independen yang berasal dari metode Pulic cukup independen satu sama lain atau ada multikolinearitas antara variabel-variabel ini. Jika variabel-variabel independen sangat berkorelasi satu sama lain, maka mereka tidak lagi independen satu sama lain. Uji multikolinearitas bertujuan untuk menguji apakah model regresi ditemukan adanya korelasi antar variabel bebas.Tabel $\mathbf{5}$.

Tabel 5. Correlation Matrix untuk Setiap Variabel

Tabel 5. Correlation Matrix untuk Setiap Variabel

Correlations

\begin{tabular}{|c|c|c|c|c|c|c|c|c|c|c|c|}
\hline & \multirow{2}{*}{$\frac{\text { VAIC }}{1}$} & \multicolumn{3}{|c|}{ VACA2006VACA2007/ACA2008 } & \multicolumn{2}{|c|}{ VAHU2006VAHU2007 } & \multicolumn{3}{|c|}{ VAHU2008STVA2006STVA2007 } & 木TVA2008 \\
\hline & Pearson Correlat & & .045 & .087 & .105 & $.966^{*}$ & $.398^{*}$ & $.394^{*}$ & .016 & $.940 *$ & $.715^{\star}$ \\
\hline & Sig. (2-tailed) & . & .819 & .658 & .596 & .000 & .036 & .038 & .935 & .000 & .000 \\
\hline & $\mathrm{N}$ & 28 & 28 & 28 & 28 & 28 & 28 & 28 & 28 & 28 & 28 \\
\hline VACA200। & Pearson Correlat & .045 & 1 & .010 & -.001 & .067 & -.100 & -.118 & -.209 & .044 & .082 \\
\hline & Sig. (2-tailed) & .819 & . & .960 & .998 & .735 & .614 & .552 & .285 & .822 & .677 \\
\hline & $\mathrm{N}$ & 28 & 28 & 28 & 28 & 28 & 28 & 28 & 28 & 28 & 28 \\
\hline VACA200 & Pearson Correlat & .087 & .010 & 1 & $.895^{\star}$ & .035 & .024 & .054 & .105 & .059 & .066 \\
\hline & Sig. (2-tailed) & .658 & .960 & . & .000 & .860 & .903 & .785 & .593 & .767 & .739 \\
\hline & $\mathrm{N}$ & 28 & 28 & 28 & 28 & 28 & 28 & 28 & 28 & 28 & 28 \\
\hline VACA200 & Pearson Correlat & .105 & -.001 & $.895^{*}$ & 1 & .059 & .021 & .039 & .149 & .092 & .098 \\
\hline & Sig. (2-tailed) & .596 & .998 & .000 & . & .767 & .915 & .844 & .449 & .643 & .619 \\
\hline & $\mathrm{N}$ & 28 & 28 & 28 & 28 & 28 & 28 & 28 & 28 & 28 & 28 \\
\hline VAHU200 & Pearson Correlat & $.966^{* *}$ & .067 & .035 & .059 & 1 & .166 & .171 & -.062 & $.972 *$ & $.723^{\star}$ \\
\hline & Sig. (2-tailed) & .000 & .735 & .860 & .767 & . & .399 & .383 & .754 & .000 & .000 \\
\hline & $\mathrm{N}$ & 28 & 28 & 28 & 28 & 28 & 28 & 28 & 28 & 28 & 28 \\
\hline VAHU200 & Pearson Correlat & $.398^{\star}$ & -.100 & .024 & .021 & .166 & 1 & $.730^{* *}$ & .235 & .151 & .157 \\
\hline & Sig. (2-tailed) & .036 & .614 & .903 & .915 & .399 & . & .000 & .228 & .443 & .426 \\
\hline & $\mathrm{N}$ & 28 & 28 & 28 & 28 & 28 & 28 & 28 & 28 & 28 & 28 \\
\hline VAHU200 & Pearson Correlat & $.394^{\star}$ & -.118 & .054 & .039 & .171 & $.730 *$ & 1 & .275 & .180 & .191 \\
\hline & Sig. (2-tailed) & .038 & .552 & .785 & .844 & .383 & .000 & . & .157 & .360 & .330 \\
\hline & $\mathrm{N}$ & 28 & 28 & 28 & 28 & 28 & 28 & 28 & 28 & 28 & 28 \\
\hline STVA200 & Pearson Correlat & .016 & -.209 & .105 & .149 & -.062 & .235 & .275 & 1 & .016 & .037 \\
\hline & Sig. (2-tailed) & .935 & .285 & .593 & .449 & .754 & .228 & .157 & . & .936 & .852 \\
\hline & $\mathrm{N}$ & 28 & 28 & 28 & 28 & 28 & 28 & 28 & 28 & 28 & 28 \\
\hline STVA200" & Pearson Correlat & $.940 *$ & .044 & .059 & .092 & $.972 *$ & .151 & .180 & .016 & 1 & $.854 *$ \\
\hline & Sig. (2-tailed) & .000 & .822 & .767 & .643 & .000 & .443 & .360 & .936 & . & .000 \\
\hline & $\mathrm{N}$ & 28 & 28 & 28 & 28 & 28 & 28 & 28 & 28 & 28 & 28 \\
\hline STVA200\} & Pearson Correlat & $.715^{\star *}$ & .082 & .066 & .098 & $.723^{*}$ & .157 & .191 & .037 & $.854^{*}$ & 1 \\
\hline & Sig. (2-tailed) & .000 & .677 & .739 & .619 & .000 & .426 & .330 & .852 & .000 & . \\
\hline & $\mathrm{N}$ & 28 & 28 & 28 & 28 & 28 & 28 & 28 & 28 & 28 & 28 \\
\hline
\end{tabular}

${ }^{* *}$.Correlation is significant at the 0.01 level (2-tailed).

*. Correlation is significant at the 0.05 level (2-tailed).

Dari tabel 5. bahwa korelasi antara variabel independen tidak terlalu tinggi. Korelasinya berkisar dari 0.135 sampai 0,839 untuk variabel-variabel independen tahun yang sama. Jadi, multikolinearitas antara set data tidak membatalkan penggunaannya. Hal ini juga menunjukkan bahwa IC Metode Pulic (VACA, VAHU dan STVA) cukup independen satu sama lain.

\section{Pengujian Hipotesis}

Analisis hipotesis lebih lanjut akan menggunakan Partial Least Square (PLS). Pemilihan metode PLS didasarkan pada pertimbangan bahwa dalam penelitian ini terdapat dua variabel laten yang dibentuk dengan indikator formative dimana kinerja diperlakukan sebagai variabel laten dengan ROA, GR dan Size sebagai indikatornya. Model itu memperlakukan IC dan kinerja perusahaaan sebagai variabel laten dengan tiga indikator tiap variabelnya karena regresi berganda tidak dapat menyediakan alat uji untuk tipe analisis ini.

\section{Pengaruh IC terhadap Kinerja Keuangan Perusahaan}

Hipotesis penelitian yang pertama diuji untuk mengetahui pengaruh $\mathrm{VAIC}^{\mathrm{TM}}$ terhadap kinerja keuangan perusahaan. Dalam hal ini IC diuji terhadap kinerja keuangan perusahaan pada tahun yang sama. Dari hasil olah data menggunakan PLS diperoleh hasil sebagai berikut: 
Tabel 6. Hasil PLS untuk H1

\begin{tabular}{|c|c|c|c|c|c|}
\hline & $\begin{array}{l}\text { original sample } \\
\text { estimate }\end{array}$ & $\begin{array}{c}\text { mean of } \\
\text { subsamples }\end{array}$ & $\begin{array}{l}\text { Standard } \\
\text { deviation }\end{array}$ & T-statistic & $\mathrm{R} 2$ \\
\hline $\begin{array}{lcc}\text { IC } & 2006 & \rightarrow \\
\text { PERF 2006 } & \\
\end{array}$ & 0,788 & 0,007 & 0,738 & 1,068 & 0,007 \\
\hline $\begin{array}{lrl}\text { IC } & 2007 & \rightarrow \\
\text { PERF } & 2007 & \end{array}$ & 0,353 & $-0,046$ & 0,529 & 0,668 & 0,046 \\
\hline $\begin{array}{lrl}\text { IC } & 2008 & \rightarrow \\
\text { PERF 2008 } & \end{array}$ & $-0,622$ & $-0,620$ & 0,068 & 9,111 & 0,620 \\
\hline
\end{tabular}

Berdasarkan tabel diatas dapat dilihat bahwa:

a. T-statistics IC 2006 versus 2006 performance lebih rendah dari 1,96; yaitu 1,068 berarti signifikan pada $\mathrm{p}>0,05$ dengan $\mathrm{R} 2$ sebesar 0,007 .

b. T-statistics IC 2007 versus 2007 performance lebih kecil dari 1,96; yaitu 0,668 yang berarti signifikan pada $\mathrm{p}>0,05$ dengan $\mathrm{R} 2$ sebesar 0,046 .

c. T-statistics IC 2008 versus 2008 performance lebih besar dari 1,96; yaitu 9,111 yang berarti signifikan pada $\mathrm{p}<0,05$, dengan $\mathrm{R} 2$ sebesar 0,620 .

Dalam hal ini, hasil diatas mencerminkan IC pada tahun 2006 dan 2007 tidak memiliki hubungan yang sangat erat, sedangkan IC pada 2008 memiliki hubungan yang erat dengan kinerja perusahaan karena R2 selama tiga tahun berturut-turut sebesar 0,007; 0,046; 0,620.

\section{Pengaruh IC terhadap Kinerja Keuangan Perusahaan Masa Depan}

Hipotesis kedua yang diajukan dalam penelitian ini adalah bahwa VAIC berpengaruh terhadap kinerja keuangan perusahaan masa depan. Artinya, IC digunakan sebagai alat untuk memprediksi kinerja keuangan perusahaan di masa mendatang. Dari hasil olah data menggunakan PLS diperoleh hasil sebagai berikut:

Tabel 7. Hasil PLS untuk H2

\begin{tabular}{|c|c|c|c|c|c|}
\hline & $\begin{array}{l}\text { original sample } \\
\text { estimate }\end{array}$ & $\begin{array}{c}\text { mean of } \\
\text { subsamples }\end{array}$ & $\begin{array}{l}\text { Standard } \\
\text { deviation }\end{array}$ & T-statistic & R2 \\
\hline $\begin{array}{lr}\text { IC } & 2006 \\
\text { PERF } 2007 & \rightarrow\end{array}$ & 0,588 & $-0,481$ & 0,438 & 1,342 & $-0,481$ \\
\hline $\begin{array}{lrl}\text { IC } & 2006 & \rightarrow \\
\text { PERF 2008 } & \end{array}$ & 0,702 & $-0,135$ & 0,696 & 1,009 & 0,007 \\
\hline $\begin{array}{lr}\text { IC } \quad 2007 \\
\text { PERF } 2008\end{array}$ & $-0,518$ & $-0,539$ & 0,080 & 6,496 & 0,539 \\
\hline
\end{tabular}

Berdasarkan tabel diatas dapat dilihat bahwa:

a. T-statistics IC 2006 versus 2007 performance lebih kecil dari 1,96; yaitu 1,342 berarti signifikan pada $\mathrm{p}>0,05$, sebesar $-0,481$.

b. T-statistics IC 2006 versus 2007 performance lebih kecil dari 1,96; yaitu 1,009 yang berarti signifikan pada $p>0,05$, sebesar 0,007 .

c. T-statistics IC 2007 versus 2008 performance lebih besar dari 1,96; yaitu 6,496 yang berarti signifikan pada $\mathrm{p}<0,05$, sebesar 0,539 .

Dalam hal ini, hasil diatas mencerminkan IC tidak memiliki hubungan yang erat dengan kinerja perusahaan karena R2 dari ketiga uji analisis diatas berturut-turut sebesar -0,481; 0,007; 0,539. Dalam sebuah model eksplorasi, R2 lebih rendah sebesar 0,10 sehingga dapat dianggap tidak memuaskan dan tidak pantas untuk pelaporan.

\section{Pengaruh ROGIC terhadap Kinerja Keuangan Perusahaan Masa Depan}

Hipotesis ketiga yang diajukan dalam penelitian ini adalah bahwa ROGIC berpengaruh terhadap kinerja keuangan perusahaan masa depan. ROGIC (rate of growth of IC) adalah tingkat pertumbuhan VACA, VAHU dan STVA perusahaan dari tahun ke tahun. ROGIC dari tahun 2006 hingga 2007 dan 2007 hingga 2008 diuji dengan kinerja perusahaan tahun 2008. 
Tabel 8. Hasil PLS untuk H3

\begin{tabular}{|ll|l|l|l|l|}
\hline & \multicolumn{1}{|c|}{$\begin{array}{c}\text { original sample } \\
\text { estimate }\end{array}$} & $\begin{array}{c}\text { mean of } \\
\text { subsamples }\end{array}$ & $\begin{array}{c}\text { Standard } \\
\text { deviation }\end{array}$ & \multicolumn{1}{|c|}{ T-statistic } \\
\hline $\begin{array}{l}\text { IC 2006 } \\
\text { PERF 2007 }\end{array}$ & $\rightarrow$ & 0,568 & $-0,488$ & 0,417 & 1,302 \\
\hline $\begin{array}{l}\text { IC 2006 } \\
\text { PERF 2008 }\end{array}$ & $\rightarrow$ & 0,708 & $-0,138$ & 0,606 & 1,019 \\
\hline $\begin{array}{l}\text { IC 2007 } \\
\text { PERF 2008 }\end{array}$ & $\rightarrow$ & $-0,507$ & $-0,508$ & 0,070 & 6,226 \\
\hline
\end{tabular}

Berdasarkan tabel diatas dapat dilihat bahwa:

a. T-statistics IC 2006 versus 2006 performance lebih kecil dari 1,96; yaitu 10,212 berarti signifikan pada $\mathrm{p}<0,05$.

b. T-statistics IC 2007 versus 2007 performance lebih kecil dari 1,96; yaitu 2,247 yang berarti signifikan pada $\mathrm{p}<0,05$.

c. T-statistics IC 2008 versus 2008 performance lebih besar dari 1,96; yaitu 4,891 yang berarti signifikan pada $\mathrm{p}<0,05$.

Dalam hal ini, hasil diatas mencerminkan IC tidak memiliki hubungan yang erat dengan kinerja perusahaan. Dalam sebuah model eksplorasi, R2 sebesar 0,10 dapat dianggap memuaskan dan pantas untuk pelaporan.

\section{Kontribusi IC terhadap Sektor-sektor Industri yang Berbeda}

Hipotesis keempat menyatakan kontribusi IC untuk sebuah kinerja masa depan perusahaan akan berbeda sesuai dengan jenis industrinya. Sesuai penelitian, data dipecah menjadi dua sektor, yaitu manufaktur dan non manufaktur.

Tabel 9. Hasil PLS untuk H4 Model Summary-Manufaktur

\begin{tabular}{|l|l|l|l|l|}
\hline & \multicolumn{1}{|c|}{$\begin{array}{c}\text { original sample } \\
\text { estimate }\end{array}$} & \multicolumn{1}{|c|}{$\begin{array}{c}\text { mean of } \\
\text { subsamples }\end{array}$} & $\begin{array}{c}\text { Standard } \\
\text { deviation }\end{array}$ & \multicolumn{1}{|c|}{ T-statistic } \\
\hline $\begin{array}{l}\text { IC 2006 -> } \\
\text { PERF 2007 }\end{array}$ & 0,702 & $-0,492$ & 0,533 & 1,319 \\
\hline $\begin{array}{l}\text { IC 2006 -> } \\
\text { PERF 2008 }\end{array}$ & 0,702 & $-0,135$ & 0,696 & 1,002 \\
\hline $\begin{array}{l}\text { IC 2007 -> } \\
\text { PERF 2008 }\end{array}$ & $-0,518$ & $-0,539$ & 0,080 & 6,496 \\
\hline $\begin{array}{l}\text { IC 2006 -> } \\
\text { PERF 2007 }\end{array}$ & 0,839 & 0,234 & 0,773 & 1,086 \\
\hline $\begin{array}{l}\text { IC 2006 -> } \\
\text { PERF 2008 }\end{array}$ & $-0,435$ & $-0,454$ & 0,307 & 1,417 \\
\hline $\begin{array}{l}\text { IC 2007 -> } \\
\text { PERF 2008 }\end{array}$ & $-0,727$ & $-0,721$ & 0,072 & 10,117 \\
\hline
\end{tabular}

Sumber : Data sekunder yang diolah

Berdasarkan tabel diatas dapat dilihat bahwa:

a. T-statistics dari path sektor manufaktur untuk kedua analisis tahun 2006 dan 2007 lebih kecil dari 1,96; yaitu 1,319; 1,002, yang berarti tidak signifikan pada $\mathrm{p}<0,05$ dan pada analisis tahun 2008, lebih besar dari 1,96, yakni 6,496, yang berarti signifikan pada $p<0,05$.

b. T-statistics dari path sektor non manufaktur untuk kedua analisis tahun 2006 dan 2007 lebih kecil dari 1,96; yaitu 1,086; 1,417, yang berarti tidak signifikan pada $\mathrm{p}<0,05$ dan pada analisis tahun 2008, lebih besar dari 1,96, yakni 10,117, yang berarti signifikan pada $\mathrm{p}<0,05$. 
Tabel 10. Kesimpulan Hipotesis

\begin{tabular}{|l|c|}
\hline \multicolumn{1}{|c|}{ Hipotesis } & Kesimpulan \\
\hline $\begin{array}{l}\text { H1: Terdapat pengaruh positif Intellectual Capital }\left(\mathrm{VAIC}^{\mathrm{TM}}\right) \text { terhadap kinerja } \\
\text { keuangan perusahaan. }\end{array}$ & DITOLAK \\
\hline $\begin{array}{l}\text { H2: Terdapat pengaruh positif Intellectual Capital (VAIC } \\
\text { keuangan perusahaan masa depan. }\end{array}$ & DITOLAK \\
\hline $\begin{array}{l}\text { H3: Terdapat pengaruh positif tingkat pertumbuhan intellectual capital (ROGIC) } \\
\text { terhadap kinerja keuangan perusahaan masa depan. }\end{array}$ & DITOLAK \\
\hline $\begin{array}{l}\text { H4: Kontribusi IC untuk sebuah kinerja masa depan perusahaan akan berbeda } \\
\text { sesuai dengan jenis industrinya. }\end{array}$ & DITOLAK \\
\hline
\end{tabular}

\section{Pembahasan}

Hipotesis penelitian yang pertama (H1) diuji untuk mengetahui pengaruh VAIC $^{\text {TM }}$ terhadap kinerja keuangan perusahaan. Dalam hal ini IC diuji terhadap kinerja keuangan perusahaan pada tahun yang sama. Hasil olah data pada Tabel 4.7 mencerminkan IC tidak memiliki hubungan yang sangat erat dengan kinerja perusahaan. Sehingga dapat diindikasikan jika IC tidak dapat berperan penting pada kontribusi kinerja keuangan perusahaan.

Hipotesis kedua (H2) yang diajukan dalam penelitian ini adalah bahwa VAIC tidak berpengaruh terhadap kinerja keuangan perusahaan masa depan. Pada Tabel 4.8, hasil olah data mencerminkan bahwa IC tidak memiliki hubungan yang erat dengan kinerja perusahaan di masa depan. Sehingga dapat dikatakan bahwa IC bukan merupakan suatu komponen utama perusahaan, sehingga sulit untuk mengukur kinerja perusahaan di masa yang akan datang.

\section{KESIMPULAN}

1. Berdasarkan hasil pengujian dengan PLS diketahui bahwa IC (VAIC) tidak berpengaruh positif terhadap kinerja keuangan perusahaan. Sehingga dengan demikian berarti H1 tidak dapat diterima.

2. Dari hasil pengujian PLS mengindikasikan bahwa IC (VAIC) secara positif tidak berpengaruh terhadap kinerja keuangan perusahaan masa depan. Sehingga dengan demikian berarti H2 tidak terbukti.

3. Dari hasil pengujian PLS menyajikan bukti bahwa tidak ada pengaruh positif ROGIC terhadap kinerja keuangan

4. Dari Hasil pengujian PLS menunjukkan bahwa kontribusi IC untuk sebuah kinerja masa depan perusahaan tidak terdapat perbedaan sesuai dengan jenis sektor perusahaannya. Sehingga dengan demikian berarti $\mathrm{H} 4$ ditolak.

\section{KETERBATASAN DAN SARAN}

1. Penelitian ini terbatas pada perusahaan publik yang listed di BEI. Saham perusahaan-perusahaan yang tidak listed dan tidak diperdagangkan, dan diharapkan untuk penelitian mendatang menggunakan sampel perusahaan yang tidak terdaftar di BEI.

2. Perusahaan yang terpilih dianalisis selama tiga tahun antara tahun 2006 sampai 2008, diharapkan penelitian mendatang menggunakan waktu pengamatan yang lebih panjang, sehingga dapat memberikan hasil penelitian yang maksimal.

\section{DAFTAR PUSTAKA}

Anatan,Lia (2004), “Modal intelektual dan kinerja perusahaan : sebuah review aplikasi manajemen modal intelektualdalam era baru manufaktur", Telaah bisnis, Vol 5 No 2

Artinah, Budi (2010), "faktor-faktor yang mempengaruhi kinerja modal intelektual" (Tesis). Semarang: Program Pascasarjana, Universitas Diponegoro.

Barney Jay, (1991) "Firm Resources and Sustained Competitive Advantage". Journal of Management. Vol 17. No 1.

Cahya, Bramantya Adhi (2010), "Analisis pengaruh kinerja keuangan terhadap tanggung jawab sosial perusahaan (corporate social responsibility) (studi pada bank di indonesia periode tahun 20072008)" (Skripsi). Semarang: Fakultas Ekonomi. Universitas Diponegoro.

Ikatan Akuntan Indonesia. (2007). Pernyataan Standar Akuntansi Keuangan No. 19, Salemba Empat. Jakarta.

Kuryanto, Benny (2007), "Pengaruh modal intelektual terhadap kinerja perusahaan" (Skripsi). Semarang: fakultas ekonomi. Universitas Diponegoro. 
Meek, G.K., and S.J. Gray. 1988. "The value added statement: an innovation for the US companies". Accounting Horizons. Vol. 12 No. 2. pp. 73-81.

Pulic, A. 1998. "Measuring the performance of intellectual potential in knowledge economy". Paper presented at the 2nd McMaster Word Congress on Measuring and Managing Intellectual Capital by the Austrian Team for Intellectual Potential.

1999. "Basic information on VAIC' ${ }^{\text {тм". }}$ available online at: www.vaic-on.net. (accessed November 2006).

2000. "VAICTM - an accounting tool for IC management". available online at: www.measuringip.at/Papers/ham99txt.htm (accessed November 2006).

and Kolakovic, M. 2003. "Value creation efficiency in the new economy". available online at: www.vaic-on.net. (accessed November 2006).

Murti, Anugraheni Cahyaning (2010), "Analisis pengaruh modal intelektual terhadap kinerja perusahaan (studi pada perusahaan yang terdaftar di bursa efek indonesia)" (Skripsi). Semarang: Fakultas Ekonomi. Universitas Diponegoro.

Pramelasari, Yosi Metta (2010), "Pengaruh intellectual capital terhadap nilai pasar dan kinerja keuangan perusahaan" (Skripsi). Semarang: fakultas ekonomi. Universitas Diponegoro.

Santoso, Yudi (2010) "Analisis pengaruh faktor leverage, dividen payout ratio, earning growth, size, dan arus kas operasi terhadap price earning ratio (per) di bursa efek jakarta periode tahun 2004 s.d 2006" (Tesis). Semarang: Program Pascasarjana. Universitas Diponegoro.

Saputro, Julianto Agung (2001), "upaya pengembangan ukuran dan pengungakapan intellectual capital dalam laporan keuangan" kajian bisnis No.22. Januari

Ting dan lean (2009), "intellectual capital performance of financial institutions in malaysia" journal of intellectual capital. Vol. 10 No. 4

Ulum, Ihyaul, (2007). Intellectual Capital dan Kinerja Keuangan Perusahaan; Suatu Analisis dengan Pendekatan Partial Least Square (Tesis). Semarang: Program Pascasarjana, Universitas Diponegoro. 